$\begin{array}{llr}\text { KULTURA } & \begin{array}{l}\text { POLSKA A KADEMIA NAUK } \\ \text { KOMITET SOCJOLOGII }\end{array} & \begin{array}{r}\text { ISSN 0023-5172 } \\ 2300-195 \mathrm{x}\end{array} \\ \mathbf{\text { I }} & \begin{array}{l}\text { INSTYTUT STUDIÓW POLITYCZNYCH } \\ \text { SPOLECENSTWO }\end{array} & \\ 2020, \text { nr 1 SWOI I OBCY. KULTURA GOŚCINY } & \end{array}$
$\begin{array}{llllllll}A & R & T & Y & K & U & 亡 & Y\end{array}$
I
$\begin{array}{llllllll}\mathrm{R} & \mathrm{O} & \mathrm{Z} & \mathrm{P} & \mathrm{R} & \mathrm{A} & \mathrm{W} & \mathrm{Y}\end{array}$

DOROTA RANCEW-SIKORA

Uniwersytet Gdański

\title{
POLSKA GOŚCINNOŚĆ \\ W ŚWIETLE ZAPISÓW AUTOBIOGRAFICZNYCH
}

\section{WPROWADZENIE}

Przedstawiane badanie jest fragmentem większego projektu poświęconego mechanizmom społecznym i znaczeniom $\mathrm{w}$ sferze gościnności ${ }^{1}$, a jego celem było zweryfikowanie autostereotypu Polaków jako narodu bardzo gościnnego przez zestawienie go z zapisami autobiograficznymi dotyczącymi sytuacji (nie)gościnnych w przekroju społecznym i czasie historycznym, co ma umożliwić dostrzeżenie ewentualnych zmian w tym zakresie.

Badanie to opiera się na materiałach autobiograficznych, które mogą dać pewien wgląd w to, jak wspominają ważne dla siebie sytuacje gościnne autorzy żyjący w społecznych i historycznych okolicznościach odmiennych od tych, które można zaobserwować lub opisać (nagrać) dzisiaj. Autorzy

\footnotetext{
Adres do korespondencji: dorota.rancew-sikora@ug.edu.pl; ORCID: 0000-0002-0608$-9136$

1 Ów szerszy projekt dotyczący gościnności, realizowany w ramach działalności statutowej w Instytucie Socjologii UG, polega na wykorzystaniu różnych materiałów i metod, takich jak analiza nagrań audio (Rancew-Sikora 2015) i video (Rancew-Sikora 2019; Rancew-Sikora, Remisiewicz 2020), wywiady (Rancew-Sikora, Żadkowska 2017; Krukowska, Rancew-Sikora 2016) czy studiowanie różnych materiałów zastanych, w tym dokumentów osobistych.
} 
wielu opracowań o charakterze teoretycznym mają skłonność do koncentrowania się na modelach normatywnych. Czy zatem zawarte $\mathrm{w}$ takich opracowaniach tezy znajdują odzwierciedlenie w dostępnych nam zapisach doświadczeń osobistych? Badania empiryczne nad gościnnością służą odpowiedzi na to pytanie i na tym między innymi, moim zdaniem, polega ich znaczenie.

Gościnność to temat socjologicznie istotny i wart zbadania, ponieważ spotkania w gościnie pomagają ludziom przekroczyć granice różnych izolowanych kręgów towarzyskich i rodzinnych, a przy tym zaobserwować i częściowo pokonać dzielące je różnice społeczne i kulturowe. Wiemy już, że jest to proces skomplikowany, złożony, wymagający wysiłku obu stron relacji gościnnej (zob. Pisarek 2016; Mateja-Jaworska, Skowrońska 2019). Trzeba zaznaczyć, że w repertuarze przyjęć gościnnych - obok poświęcenia, samoograniczeń, życzliwych gestów i troski — jest też miejsce na zagrania strategiczne, polegające na unikaniu ryzyka oraz dążeniu do powiększania własnych zasobów i wpływów (zob. Pitt-Rivers 1968, 2012; Derrida 2000; Pisarek 2016; Skowrońska 2019).

W literaturze zauważalna jest tendencja do traktowania gościnności raczej jako interakcji nawiązywanej z Innym - przybyszem, obcym (stranger), czyli osobą usytuowaną w jakimś zewnętrznym otoczeniu, które może być odmienne kulturowo (Kant 1995; Levinas 1998; Marotta 2005; 2011; Simmel 2005; Schütz 2008a, 2008b; Wood 1934). Chciałabym jednak zauważyć, że gościnność wobec osób obcych i bliskich może mieć znacząco różniące się znaczenia społeczne. Przyjmowanie u siebie w domu osób niemieszkających w jednym gospodarstwie domowym, ale dobrze zaznajomionych, spokrewnionych, bliskich nie tylko w polskich warunkach ma ważne znaczenie dla podtrzymywania więzi w obrębie już istniejących kręgów i kultywowania ich tradycji kulturowych, a także bierze udział w regulowaniu pozycji społecznych zaangażowanych uczestników (zob. Komorowska 1984; Pisarek 2016; Straczuk 2013).

Poszczególne dyscypliny naukowe kładą zróżnicowany akcent na zmienne kulturowe i społeczne, badając gościnność. Gdy antropologia koncentruje się na aspektach (między)kulturowych takich spotkań (zob. Candea, da Col 2012; Gibson 2003; Lynch i in. 2011; Selwyn 2000), dla socjologicznego ujęcia bardziej charakterystyczne jest zwracanie uwagi na znaczenie $w$ relacjach gościnnych zmiennych środowiskowych, statusowych, klasowych oraz tych związanych z wiekiem, pokoleniem i płcią (Lashley i in. 2006; Lashley, Morrison 2000; Małkowicz-Daszkowska 2019; Rancew-Sikora 2015; Rancew-Sikora, Żadkowska 2017; Skowrońska 2014, 2019). Jednym z pierwszych socjologów, którzy dostrzegli znaczenie tego 
tematu, był Florian Znaniecki (1938, s. 98-100). Twierdził, że gościna jest głęboko zakorzenioną w społecznym kontekście hierarchii i zróżnicowania zasobów formą relacji, w której występują specyficzne strategie, cele, zobowiązania i prawa. Gościnność obejmuje wykonanie pracy nad zmniejszaniem potencjalnych zagrożeń z zewnątrz, a więc wymaga wstępnego rozpoznania sił (społecznych lub magicznych), jakie stoją za przybyszami i skłonienia czy wręcz przymuszenia ich do dobroczynności (Znaniecki 1938, s. 106-107).

„Osobnik nieznany, przybywający do siedziby rodzinnej w roli gościa, musi wykazać, skąd przybywa, do jakiego należy zespołu i kim jest w tym zespole. Jego ważność jako gościa zależy od ważności zespołu, który reprezentuje, oraz ważności jego własnej roli w tym zespole, a także od tego, co konkretnie wnosi ze sobą — czy to będzie błogosławieństwo, czy jakiś dar, rada, wiedza, opowieść, czy umiejętność. Odpowiednio też wyznacza mu się jako gościowi mniej lub bardziej ważne stanowisko. Zawsze jednak jest to daleko wyższe stanowisko niż to, które zajmują członkowie własnego zespołu rodzinnego w odpowiednich rolach, gdyż jego osobie przysługuje swoista godność przedstawiciela" (Znaniecki 1938, s. 99).

Gościnność to temat w Polsce istotny, bo skupia się na pozytywnym aspekcie zbiorowego autostereotypu, wyróżnianym spośród innych jako powód do dumy i będącym żywym, trwałym elementem kultury narodowej (CBOS 2010; Cieśla 2017). Stereotyp gościnnego Polaka ma bardzo długie tradycje, odnajdujemy go między innymi w pismach z XV wieku (Jan Długosz [1961, s. 103]: „Szlachta polska [...] dla obcych i gości ludzka i uprzejma, celuje nad innymi narodami gościnnością), z XVI wieku (Marcin Kromer [1961, s. 177]: „Polak jest towarzyski, grzeczny, uprzejmy i skory do gościnności tak dalece, że nawet ludzi nieznanych i obcych nie tylko rad gościnnie przyjmuje, lecz owszem zaprasza i ze wszelką uprzejmością im służy; a nie dosyć, iż się chętnie skłania do towarzyskiej poufałości, lecz owszem giętki jest do przejmowania i naśladowania obyczajów tych, z którymi żyje, zwłaszcza cudzoziemców") i z XX wieku (Władysław Łoziński [1961/1912, s. 312-313]: „Wszystkie bowiem zalety towarzyskie: uprzejmość, wesołość, nieusuwanie się od ochoty sąsiedzkiej i przyjacielskiej, a przede wszystkim gościnność, obejmowało w dawnej Polsce słowem «ludzkość». Jednego wszakże brakło w życiu towarzyskim, choć go zapewne nie brakło w kodeksie grzeczności, a to panowania nad sobą".

Kultywując ten stereotyp, trzeba jednak uważać, aby nie utrwalać zakamuflowanych w oczekiwaniach społecznych nierówności społecznych, wpadając $\mathrm{w}$ pułapkę uczynienia z gościnności tematu opartego głównie 
na nostalgii i mrzonkach lub nadmiernie zideologizowanego, przed czym można się uchronić mając $\mathrm{w}$ pamięci kulturowe uwikłania polskiej historii i tożsamości narodowej. Figura „polskiej gościnności” razem z innymi „polskimi cnotami” może wywyższać własną zbiorowość (a dokładniej: jej uprzywilejowane części) kosztem wykorzystywania i poniżania innych (także wewnętrznych zapoznanych „innych”), jeśli nadmiernie akcentuje się ciągłość, czystość, jednolitość polskiej tożsamości w powiązaniu jej $z$ tradycjami szlacheckimi i katolickimi (Janion 2009). Jerzy Jedlicki (2002, s. 19-24) podobnie ostrzega, że polska gościnność może nie być tematem neutralnym i należałoby ją rozumieć i tłumaczyć w odniesieniu do innych dylematów i konfliktów wartości, które występują w Polsce intensywnie i nieprzerwanie co najmniej od XIX wieku, a polegają na przeciwstawieniu romantycznego przywiązania do tradycji i idei własnej swoistości dążeniu do postępu i modernizacji, podejmowanym w bliskich relacjach z Zachodem.

\section{BADANIE (NIE)GOŚCINNYCH DOŚWIADCZEŃ AUTOBIOGRAFICZNYCH - ZARYS METODY}

Analiza została przeprowadzona według autorskiego pomysłu badań skoncentrowanych na porównywaniu raczej wyizolowanych epizodów wspomnień niż całościowych narracji biograficznych, a przyjęcie takiej strategii znajduje potwierdzenie w psychologicznych mechanizmach funkcjonowania autobiograficznej pamięci epizodycznej (zob. Conway, Pleydell-Pearce 2000). Dotychczasowe koncepcje gościnności zwykle były oparte na modelach ogólnych, o nachyleniu filozoficznym (Derrida 2000; Kant 1995; Levinas 1998) lub kulturowym; były też ograniczone do określonych kontekstów historycznych i środowiskowych (np. obyczajowość szlachecka, chłopska, salony mieszczańskie, inteligenckie i artystyczne, działanie kręgów politycznych). Natomiast powzięty zamiar badawczy miał służyć weryfikacji i zrównoważeniu prawomocności tych ogólnych tez przez dobór bardzo zróżnicowanych materiałów biograficznych sięgających w czas historyczny. Takie podejście jest związane $z$ dyskursem tzw. polskiej gościnności, ale widzianej z perspektywy jednostkowych, osobistych doświadczeń, które zostały zapamiętane i wbudowane do opowieści biograficznych o własnym życiu (zob. Czyżewski 2016; Doliński 2012; Kaźmierska 2008; Kulas 2016).

Wykorzystane materiały autobiograficzne obejmują ważny okres formacyjny społeczeństwa polskiego i w większości dotyczą końca XIX i pierwszej połowy XX wieku. W celu poszerzenia perspektywy interpre- 
tacji włączono także nieco materiałów sprzed tego okresu i po nim. W warunkach ograniczonej dostępności zapisanych i opublikowanych wspomnień zastosowano trzy podstawowe kryteria doboru celowego:

a) autorzy (ze względu na ich zróżnicowane usytuowanie w strukturze społecznej);

b) opisywane sytuacje ( $z$ uwzględnieniem zróżnicowania kontekstu historyczno-społecznego i biograficznego);

c) jakość opisu epizodu (głównie ze względu na obfitość szczegółów dotyczących czasu, miejsca i przebiegu sytuacji gościny).

W okresie, do którego sięgam, organizowano w Polsce wiele konkursów na pamiętniki, upowszechniło się też publikowanie wspomnień w formie książkowej, nie tylko przez zawodowych literatów. Życie prywatne, w którego zakres wchodzą sytuacje gościny, z jego związkami międzyludzkimi i uczuciami, stało się ważne, jego badanie służyło odkrywaniu szczegółów codzienności, do dziś nadal niewystarczająco opracowanych naukowo. Dzięki temu w szerszym zakresie ujawnił się także punkt widzenia kobiet oraz przedstawicieli klas ludowych, dla których inne formy publicznego przedstawienia subiektywnej perspektywy wcześniej były niedostępne. Włączone do analizowanego zbioru wspomnienia Juliana Ursyna Niemcewicza sięgają czasów najdalszych, z przełomu XVIII/XIX wieku, a najpóźniejsze są wspomnienia Mariana Brandysa $z$ lat siedemdziesiątych XX wieku. Łącznie zebrałam ponad 300 stron maszynopisu cytatów związanych z opisami gościnności i wyodrębniłam około 300 opisów sytuacji gościny z 30 pozycji źródłowych².

Jak wyżej wspomniałam, w doborze dokumentów osobistych sieci zostały zarzucone szeroko, aby zapewnić możliwość zestawienia różnych kontekstów społecznych i sytuacyjnych, i nie zamykać się w charakterystykach poszczególnych typów czy stylów gościnności, cechujących dane miejsca, czasy, obyczaje, kręgi społeczne czy domostwa. Pytania badawcze dotyczyły następujących kwestii:

- Jakiego rodzaju gościny zostały uwzględnione we wspomnieniach?

- Co konkretnie zostało ujęte w opisie sytuacji gościny?

- Jakie znaczenie autorzy wspomnień nadawali określonemu epizodowi?

- Co z badania ujęć autobiograficznych wynika dla naszego rozumienia znaczenia społecznego sytuacji gościny?

Podstawowa strategia badawcza polegała na zestawieniu ze sobą różnych opisów sytuacji gościny, aby zobaczyć, które ich elementy lub aspekty

\footnotetext{
${ }^{2}$ Lista znajduje się w zamieszczonej na końcu Bibliografii.
} 
były powtarzane w opisach, a które były wyjątkowe w danych okolicznościach oraz $\mathrm{w}$ jaki sposób zmieniały się $\mathrm{w}$ czasie. Poniższa prezentacja fragmentów materiałów dotyczy kolejno: wspomnień pierwszej gościny, tendencji do idealizowania sytuacji gościny, zmian gościnności w warunkach przekształceń struktury społecznej oraz sytuacji gościny w kryzysowych warunkach zagrożenia. Nie muszę dodawać, że wybrany zakres problemowy nie obejmuje wszystkich możliwych wątków wyłaniających się $z$ analizy osobistych wspomnień, ale są to - w mojej ocenie - wątki narzucające się uwadze i społecznie istotne.

\section{BIOGRAFICZNE ZNACZENIA GOŚCIN W WARUNKACH WZGLĘDNEJ STABILNOŚCI}

We wspomnieniach gościn gesty czynione na poziomie materialnym, związane $z$ wchodzeniem/wpuszczaniem kogoś do pewnej przestrzeni i dawaniem/otrzymywaniem konkretnych rzeczy, wyrażają istotne znaczenia społeczne, podobnie jak wymiana darów (Mauss 1973, s. 229). W świetle wielu analizowanych relacji podstawowe kryterium wyboru danego wspomnienia gościny jako wystarczająco ważnego, aby zamieścić je w opisach własnego życia, stanowił fakt, że była to sytuacja „pierwszego wejścia”, które dla gości oznaczało przekroczenie granicy zamkniętego, niedostępnego dla nich wcześniej „świata”. Okoliczności tych pierwszych wejść były bardzo różne - czasem było to nowe sąsiedztwo, osiągnięcie odpowiedniego wieku lub umiejętności, podróż na wieś lub do miasta, a w końcu awans społeczny - i pojawiająca się szansa na spełnienie towarzyskich aspiracji.

Przekroczenie granicy czy bariery symbolizowanej przez dotychczas zamknięte drzwi było możliwe dzięki uzyskaniu zaproszenia/akceptacji gospodarzy lub na skutek wprowadzenia przez uprawnionego gościa, ale we wspomnieniach zdarzały się też „wejścia niepełne” — do ich domu, ale bez ich wiedzy. Pierwsze wejście polegało zwykle na pokonaniu stosunkowo niewielkiego dystansu (w górę) w hierarchii społecznej. Różnica, bardzo istotna dla osoby wchodzącej, była prawie niezauważalna $z$ zewnątrz, bo dokonywała się w obrębie określonej klasy czy warstwy w warunkach istnienia subtelnych różnic prestiżu oraz niezależnych, względnie zamkniętych towarzyskich i rodzinnych kręgów. Czasem była to tylko jednorazowa wizyta, zapamiętana na całe życie, a czasem początek serii analogicznych wizyt — obie sytuacje były znaczące dla opisującego je podmiotu. Mimo że w rozważaniach teoretycznych dotyczących "przyjmowania innego" często podkreśla się znaczenie jakości spotkania uczestników gościny (zwłaszcza 
gospodarzy z gośćmi), w pamiętnikach mniej ważne zdawało się osiąganie szczególnej osobowej łączności czy prawidłowe spełnienie rytuałów grzecznościowych niż samo wejście do nowego kręgu (domostwa). Nawet spotkanie krótkie, powierzchowne czy zapośredniczone przez rzeczy było rodzajem odkrywczego przeżycia i niosło potencjał zmiany.

Cytat 1. (Paulina Wilkońska [1815-1875] 1959, wyd. org. 1871, s. 28):

Nadszedt tedy ów piątek pierwszy. Z bijacym sercem weszłam po wschodach pawilonu Kazimirowskiego pałacu. Przy drzwiach salonu powitała nas poważna postać gospodarza domu - znanego w świecie uczonym. Pani Lewocka, mile uśmiechnięta, powiodła mnie do koła pań kilku. Po godzinie ósmej salon ożywiać się począt i zapetnito go niebawem wszystko, co Warszawa znakomitego w swoich murach mieścita.

Cytat 2. (Jan Słomka [1842-1932] 1929, rozdz. VI):

Gdym byt wyrostkiem, pociagną mię raz na muzykę stużacy od sasiada, starszy odemnie. A nietrudno mi było wymkną́ się na zabawę, jeździtem bowiem z końmi na nocna paszę, więc można byto konie na pastwisku dobrze spętać $i$ wybiec do miasta. Wyjeżdżając wtedy, wziątem czysta kamizelę pod stara sukmanę, jak mi doradzit ów stużący.

Cytat 3. (Józef Świdrowski [wsp. z lat 1906-1939] 1980, s. 43-45):

$Z$ mego dzieciństwa pamiętam jeszcze jedno "wielkie wydarzenie”: babcia wzięła siostrę i mnie do swej znajomej, nazywanej przez nasza rodzinę kuma albo kuma Karpińska (jako że babcia trzymała do chrztu jej dziecko) na wesele jej córki. [...] Przyjęcie u kumy wydało mi się po prostu królewskie: jedzenia i picia byto $w$ bród, goście jedli, pili i tańczyli przez dwa czy też trzy dni i noce. Można sobie wyobrazić, jak to przyjęcie odbiło się na codziennym życiu Karpińskich i jak przyczynito się do głodowania na przednówku. Piaszczyste ziemie mazowieckie nie dawaty wielkich plonów. Ja rozkoszowatem się szczególnie piciem jeszcze cieptego mleka prosto od krowy.

Z zestawienia tych i podobnych relacji dotyczących pierwszego wejścia wyłania się możliwość rozumienia wydarzeń gościnnych jako istotnego mechanizmu ruchliwości społecznej, gdyż ukazywane są one jako życiowe i towarzyskie przełomy w skali biograficznej. Wspomnienie tego rodzaju zawiera opis zarówno dosłownego, jak i symbolicznego „wejścia”, wraz z cechującym je efektem świeżości, zaskoczenia - które usprawiedliwia ich zapamiętanie oraz wyjaśnia skrupulatność dokonanej obserwacji i opisu. Autorzy często zauważali i wyrażali swoje zdziwienie odmiennością, które zarówno mogło dotyczyć stosunkowo bliskich w hierarchii społecznej kręgów, jak i obejmować zdarzenia wyjątkowe ze względu na spotkania zachodzące na przecięciu obcych sobie i towarzysko oddzielonych środowisk społecznych i kulturowych (do takich sytuacji powrócę w części poświęconej gościnom w warunkach kryzysowych). Bardzo charakterystyczne było to, że mimo dużego zróżnicowania społecznych i biograficznych 
kontekstów gościn oraz klimatu emocjonalnego stanowiącego zwykle mieszaninę lęku i zachwytu kwestia ważności pierwszych wejść nie ulegała zmianom.

Efekt nowości lub przełomu biograficznego był opisywany także przez gospodarzy nawiedzanych przez nowego, po raz pierwszy spotkanego u siebie gościa. Dwa poniższe fragmenty wspomnień ukazują perspektywę dziecka gospodarzy, niepełnego uczestnika gościny, ale za to bystrego jej obserwatora i odbiorcy. Szczególnie drugi z poniższych fragmentów wywiera duże wrażenie ze względu na niewspółmierność wartości podarku od cioci, pochodzącej z dalekiego, nieznanego i wyobrażanego świata, do efektu jego posiadania na jakiś czas zmieniającego pozycję obdarowanego chłopca w wiejskiej grupie dziecięcej.

Cytat 4. (Alfred Wysocki [1873-1959] 1974, s. 22)

Pamiętam jako dziecko pierwsza wizytę nowo osiadtego sąsiada rodziców, starego kawalera. Sprawdziliśmy potem $z$ ojcem, że $w$ domu chadzał na co dzień $w$ tak zwanych gaciach, wiązanych na kostce sznurkiem, $w$ nocnej koszuli i w kiltu noszacym ślady rozlicznych zajęć tego pana. Do nas przyjechat jednak czwórka koni zaprzężona do lekkiego faetonu, w jasnym świeżo upranym kitlu chroniacym go od prochu i ptóciennej czapce $z$ daszkiem.

Cytat 5. (Pamiętnik chłopski nr 1363/222 Z.M.W. z pow. Kobryń, Adam, syn dworskiego parobka, ur. 1909 r., Chałasiński 1984, s. 165-166)

Otóż jednego pięknego letniego dnia $i$ to dzień byt jakiegoś uroczystego święta do kturego pamiętam, że się szykowano nie jak zwykle, powiada mi moja matka: „Adamek dzisiaj przyjedzie w goście twoja ciocia, ktura zamieszkuje w Wilnie", kturej dotychczas nie znałem, a więc zaczałem mażyć $i$ wyobrażać sobie jej wyglad jej miejsce zamieszkania. Wyobrażatem sobie że Wilno to taka sama wioska jak nasza [...] Puźniej gdy owa ciocia odpoczyła po podruży, rozpakowała swój węzetek, ktury przyniosła $z$ soba $i$ wyjęta maty gliniany gwizdek, ktury byt pomalowany na czerwono $i$ dała mnie, któżby potrafit opisać moją radość. Potem wyjęta jakąs szmatkę o czarnym kolorze, zaczęła wołać chodź chtopaczku włożę ci nogawiczki które przywiozłam ci na pamiatkę, żebyś pamiętał o mnie jak ja pojadę odwas; gdy poczutem na sobie owe majteczki pamiętam że zrobiło mi się jakoś wstyd wobec moich kolegów, które zaraz poprowadzili mnie na dwór, ażeby zaprezentować się moim podarunkiem od cioci chodzitem jak spętany, a ostrożnie żeby gdzieś nie dotknać się czegoś, pozbiegali się dzieci które z zazdrością ciekawościa ogląali wszystkie guziczki obracając mnie naokoto zaciekawieni takimi małemi spodenkami zaraz już nie chodzitem na szarym końcu, a jakby otoczony czeladzia znajdowatem się w środku. A więc przez te majteczki zarznęta się głęboko w mym sercu pamięć wizyty mej cioci, której już nigdy nie widziałem, bo po odjechaniu za jakiś czas zachorowała i zmarta. Ale gdy spojżę na te nogawiczki odrazu zaczynam wyobrażać sobie swoim ptasim mózgiem, że te nogawice przywiezione sa gdzieś tam hen $z$ dalekiego miasta, które znajduje się na końcu świata i z tego domu co stoi jeden na drugim i gdzie stowa leca jakby ptaki po żela- 
znych sznurach $i$ tak wszystkie niepojęte mi dziwy pozostały w moim ptasim mózgu od czasu do czasu przypominając sobie owe dziwa utrwalałem sobie w pamięci.

Wspomnienia z gościny podlegały niekiedy wyraźnemu procesowi idealizacji lub wręcz mitologizacji, co było z perspektywy autora lub autorki zrozumiałe, uwarunkowane tym, jak się sytuowali w świecie, jak kształtowali swoją tożsamość i jak pielęgnowali pamięć dobrych doświadczeń. Idealizacje te nie dotyczyły gościnności w ogóle czy szczególnie szczodrej gościnności polskiej, ale miały raczej charakter kontekstowy $\mathrm{i}-\mathrm{z}$ punktu widzenia narracji biograficznej - strategiczny. Idealizacja - wyprzedzająca, prospektywna, odzwierciedlona we wspomnieniach - polegała na ukazaniu wyobrażeń i nadziei osoby „wchodzącej” do nieznanego domu, wynikających z jej dążeń i aspiracji. Narratorka (cytat 1) wspominała środowisko, do którego wchodziła, jako spójne pod względem wartości: wnętrze, potrawy, rozmowy, osoby — wszystko wydawało się jej „wspaniałe”, „piękne” i „wyjątkowe” właśnie dlatego, że swoje wejście postrzegała jako osobistą szansę. Przejście do nowego kręgu miało wyraźny związek z rozpoczynaniem nowych etapów kariery biograficznej, takich jak przejście $z$ dzieciństwa $w$ dorosłość, od panieństwa do stanu małżeńskiego lub dopuszczenie do ekskluzywnego kręgu na skutek zauważonego sukcesu literackiego lub awansu towarzyskiego.

Idealizacje retrospektywne skierowane były w stronę tych kręgów, miejsc, czasów, które zostały już utracone, a dotyczą gościnności w domu rodzinnym $z$ okresu dzieciństwa i młodości, młodzieńczych kręgów towarzyskich, okresu przedwojennego jako czasu, w którym zaistniały najpiękniejsze przeżycia, utraconego wiejskiego majątku. Idealizacje skierowane w przeszłość miały nieco inny charakter niż wspomnienia pierwszego wejścia, bo zazwyczaj nie odnosiły się tylko do jednego zdarzenia, umieszczonego w określonym miejscu i czasie, ale raczej do „typowego”, uśrednionego scenariusza gościnnych spotkań, który ukazywał ,jak to bywało" i powtarzało się wielokrotnie, często cyklicznie w związku z wakacjami lub obchodzeniem świąt. Zróżnicowanie konkretnych sytuacji z tej perspektywy nie miało żadnego znaczenia, bo gościnne spotkania stanowiły znak pewnej większej całości, realizację kultury, obyczajowości czy stylu życia, które przeminęły. Warto wspomnieć, że opisane tendencje idealizacji pojawiały się przede wszystkim we wspomnieniach przedstawicieli wyższych warstw społecznych.

Cytat 6. (Paulina Wilkońska [1815-1875] 1959, s. 25):

[...] mieszkałam $w$ Warszawie i nader miłe na zawsze dała mi wspomnienie. Zaznałam w dawnej Wazów stolicy zacnossć, szlachetność, poczciwość, podniosłe obowiązku 
poczucie, miłość goraca dla kraju i wspótbraci. Zamiłowanie języka i piśmiennictwa naszego. Pracę na niwie inteligencji ojczystej: pracę $i$ walkę o nia i dla niej! A doznałam osobiście życzliwości szczerej i objawów przyjaźni rzadkiej. Nadto, ileż to tam godzin, ile wieczorów przebyłam wesotych! O łzach i bólach, onych cierniach żywota dotkliwych, krwawiacych, tutaj na teraz mówić nie będę, raczej pragnę tylko świetlejsze w pamięci pochwycić smugi - gwiazdki niebieskie, niezabudki i róże.

Cytat 7. (Zofia Szymanowska [zm. 1946] 1980 [1935], s. 57-58):

Po wilii schodzili się goście bliżsi $i$ dalsi. W tym dniu zreszta „dalszych” nie byto. Każdy każdemu byt bliski $i$ każdy byt mile widziany. W salonie petno było ludzi, $\dot{z} y$ czeń i przyjaźni. Papa i stryj Marcin w otoczeniu ciotek i wujów opowiadali anegdoty, $z$ których najgłośniej śmiał się kochany ksiądz Bayer, popijając ze znawstwem reńskie wino. Młodzież skupiwszy się po kątach, rozprawiała zawzięcie. Ktoś z kimś flirtowat, ktoś komuś wyznawat swa miłość, ktoś zapewne cierpiat trochę. A wśród tego rozbrzęczanego jak pszczeli rój ttumu krażzyty onieśmielone, suto obdarowane dzieci, którym dziś nie kazano išć wcześnie spać.

\section{GOŚCINNOŚĆ W WARUNKACH ZMIAN SPOŁECZNYCH I KRYZYSÓW}

Przywołane wyżej opisy sytuacji gościny, będące częstym obiektem wspomnień, odnosiły się zasadniczo do warunków stabilizacji społecznej, w których dokonywał się ruch jednostki w stronę zamkniętego wcześniej kręgu. Ważne jest jednak, aby zarysować także tendencje zmian społecznych w sferze życia towarzyskiego, następowujących wraz ze zmianami gospodarczymi i politycznymi, które wyjaśniały wspomniane sytuacje utraty, a także prowadziły do stopniowego przekształcania się hierarchii i zmian znaczenia poszczególnych warstw społecznych i ich stylów życia, co najogólniej rzecz biorąc - można ująć pod nazwą demokratyzacji stosunków towarzyskich (zob. Gomulicki 1959; Janaszek Ivanickowa 1971; Kulas 2017). Zmiany te polegały między innymi na wzroście różnorodności i niepewności co do wskaźników prestiżu, stopniowej autonomizacji pozycji towarzyskiej kobiet, tworzeniu alternatyw spotkań towarzyskich i ich wzmacnianiu (inteligencja, mieszczaństwo, wspólnoty ideologiczne) oraz podkopywaniu legitymizacji dominacji kulturowej sfer wyższych. Przełamywaniu i kwestionowaniu dotychczas istniejących wzorów zachowań i barier społecznych towarzyszyły nawroty do tradycji dworskich i chłopskich, co tworzyło - najogólniej rzecz biorąc - pewne zamieszanie obyczajowe w Europie (Cymbrowski 2017; Elias 2011; Smoczyński, Zarycki 2017; Wasilewski 2011).

Pierwszy przykład z tej kategorii ukazuje wymuszone przez władze carskie zderzenie dwóch „kultur gościnnych”. Przeciwstawiona została w nim: dworska powściągliwość polskich rodzin ziemiańskich i niepoha- 
mowanie moskiewskich żołnierzy (zob. Elias 2011). Stosunki te zostały ujęte w kategoriach trudnego do zniesienia szoku kulturowego, który choć opisywany był pod kątem różnic narodowych, najwyraźniej dotyczył różnic społecznych o charakterze klasowym.

Cytat 8. (Julian Ursyn Niemcewicz [1757-1841] 2000, wyd. org. 1823, s. 9):

Stanąt u nas kapitan Kisliński [?] nastajaszczy Moskal, jeszcze pót prawie dziki. Nie byli Moskale tym, czym sa dzisiaj, żadnej obyczajności, nie umieli ni jeść, ni pić. Sztab stat $w$ Brześciu. Zaczęty się biesiady i nieznane dotąd $w$ Polszcze zaloty do kobiet mężatek. Trudno wyrazić zgrozę, z jaka cnotliwa matka moja i tyle zacnych matron mówito o takich zgorszeniach. Coraz się one bardziej szerzyty. Dawali jeneratowie moskiewscy bale, zapraszajacc, pod niebezpieczeństwem prześladowania, o mil kilka obywatelstwo. Nawzajem i ich zapraszać potrzeba było. Nic wyrazić nie może rozwiazzości i zbytku hulatyk tych.

Kontrastowo odmienny jest poniższy przykład gościnnych relacji między polskimi a rosyjskimi dworami (cytat 9), choć warto zaznaczyć, że dotyczy on czasu późniejszego o cały wiek, bo sytuacja ma miejsce pod koniec zaborów, a już Niemcewicz w swoim wczesnym wspomnieniu zauważał postępujące za jego życia cywilizowanie obyczajów moskiewskich gości.

Cytat 9. (Zofia Szymanowska [zm. 1946] 1980 [1935], s. 74-75)

Byliśmy wszyscy zżyci ze soba, tym bardziej iż czuliśmy się dość odosobnieni w naszych rozrzuconych na kresach majatkach, otoczonych zwartym kotem przez lasy, grunta i cukrownie wtaściciel Rosjan. Byta to liczna w okolicy rodzina Dawydowych. Przyznać muszę, iż byli to ludzie mili i wykwintni. Polityka nie zajmowali się wcale, a dla sąiadów swych Polaków mieli wiele sympatii i przyjaźni. Mówiliśmy z nimi zawsze po francusku, gdyż przez wysokie poczucie delikatności w naszym domu nie używali nigdy rosyjskiego języka.

Na przykładzie wspomnień dwudziestoletniego Żeromskiego, wówczas guwernera, możemy z kolei zobaczyć, jak wyłanianiu się inteligencji towarzyszyło budowanie krytycznego dystansu do reprezentantów mieszczaństwa obserwowanych przy wspólnym stole z bliska i $z$ dużą dozą złośliwości.

Cytat 10. (Stefan Żeromski [1864-1925] 1964, s. 81-82):

Nie wiedziałem, że czeka mnie $w$ tej Warszawie takie mite życie jak obecne. $\dot{Z} y$ dowska dystynkcja przyprawiona sosem konwersacji francuskiej $w$ czasie obiadów $i$ kolacyj, nadzwyczaj zajmujące dyskusje o świeżo spadtym śniegu, o balu dzisiejszym, o maskaradzie jutrzejszej, lub jeszcze milsze bawienie tego matego Żydziala opowiadaniem polowan i bitew, gry z nim w szachy, spacery, stuchanie jego paplaniny [...] Niedawno to było, cztery miesiace temu, gdy bytem w Biatej i przyszła idealna pani Korzeniowska z idealniejsza jeszcze córką. Jedliśmy kolacją. Pani Korzeniow- 
ska unosita się nad czymś, pan Leon jadt kotlety i udawat, że stucha, pan Saturnin uśmiechat się — i ja śmiatem się catą duszą.

Krytyka i odrzucenie jako oznaczenie kierunków aspiracji prowadziły tu nie tyle wzwyż społecznej hierarchii, ile ku wytwarzaniu kierunków innych, nowych, czasem słabo określonych, ale wyznaczanych w duchu gotowości do rewolucyjnej zmiany kulturowej. Postawy takie, widoczne wśród przedstawicieli inteligencji i działaczy politycznych, mocno wpływały na życie towarzyskie i prowadziły do powolnych, czasem trudno zauważalnych, ale długotrwałych i nieodwracalnych procesów rozpadu starych i wytwarzania nowych podstaw solidarności społecznej i hierarchii.

Cytat 11. (Helena Bobińska [1887-1968] 1963, s. 21-22)

— Tylko wielka idea, tączaca ludzi, może stwarzać takie przyjaźnie. — To zdanie mamy trafiało nam, młodym, do przekonania. Przecież i nasza wspólna przyjaźn zrodzita wielka idea. Naszym chtopcom mama imponowała swoim oczytaniem. [...] Po kolacji mama siadała zwykle do fortepianu. Wtedy robiło się od razu cicho. Obszerna otomana $w$ rdzawe liście na mszystym tle pomiędzy oknami mogła pomieścić wielu stuchaczy. - Ja dopiero tutaj, na tej otomanie, nauczyłem się stuchać muzyki - wyznawat później niejeden $z$ naszych chłopców.

W materiałach autobiograficznych znajduje się sporo wspomnień gościn, które odbyły się w sytuacji gwałtownego załamania stabilności i przerwania procesów zmian ewolucyjnych na szerszą, społeczną skalę, gdy na ich tle zarysowały się osobiste, traumatyczne doświadczenia autorów. W XIX i XX wieku na ziemiach polskich było sporo takich kryzysowych zdarzeń, które do życia jednostki wprowadzały nieprzewidzianą i nagłą potrzebę bycia ugoszczonym lub ugoszczenia innych.

Pamiętniki bezrobotnych $z$ lat trzydziestych XX wieku są wstrząsającym zapisem doświadczania kryzysu ekonomicznego, podczas którego ludzie chętni i zdolni do pracy, czasem posiadający spore umiejętności, doświadczenie i wykształcenie nie mieli szansy wydostania się z sytuacji wykluczenia - wykluczenia także z gościnnych kręgów, które tylko przez czas jakiś, na początku, mogły trochę pomóc. Z czasem gościnne gesty zostały wykorzystane i nie doprowadziły do zmiany naprawczej, a jednocześnie stały się już niedostępne dla bezrobotnego ze względu na cechy wymagane od gościa: czystość, opanowanie głodu, posiadanie odpowiedniego ubrania czy zwykłe poczucie wartości bycia „towarzystwem” dla kogoś. Wszystkie te społeczne wymagania, ustępując przed dojmującą potrzebą ciepła i jedzenia, stały się warunkami wykluczającymi, nakazującymi odmówić zaproszeniu „żeby się nie okazało jak jest naprawdę”, nawet 
za cenę jeszcze bardziej dojmującego głodu, ale w obronie własnej godności. W gościnie głód i bieda mogą stać się ewidentne, a więc odmowa przyjęcia zaproszenia pozostaje jedyną (ostateczną) strategią obrony własnego Ja (zob. Goffman 1981, 2006).

Cytat 12. (Pamiętnik bezrobotnego nr 3, 1967 [1931], s. 94):

Dzień. Głowa mi zmarzła, chowam się bardziej pod kołdre, żeby się zagrzać, kiszki mi się skręcaja od głodu, boli żotądek. Co jest? Co dziś będzie? Wychodzę na miasto. W mieszkaniu zimno, ponuro. Ani grosza, ani kawatka chleba, ani czym napalić $w$ piecu. Czy mogę siedzieć w domu? Nic mnie nie ciagnie do siedzenia $w$ tej nędzy. Na ulicy weselej, gdy się patrze na tych, co maja, sam nie jestem tak biedny. Bytem u znajomych. Człowiek bez skruputów. Zarabia. Jeżeli zarabianiem nazywa się oszukiwanie bliźnich w bezczelny sposób. Wyśmiewa się ze wszystkich, którzy mają mu to za zte. Trafitem w czasie obiadu. Zapraszaja mnie do stotu. Robia to $w$ ten sposób, jakby mi wyrządzali nadzwyczajna łaskę. Dziękuję, wtaśnie za pół godziny muszę być $w$ domu na obiedzie. Skłamałem. Siedzę i przegladam gazetę. Nic nie widzę. Czuję zapach zupy, cielęciny smażonej, kompotu z jabłek. Udaję zaczytanego. Nieznacznie tykam ślinę. Jeszcze nie wyjdę. Wtaśnie posiedzę, niech nie pomyśla, że jestem głodny.

W sytuacjach przekroczenia dużego dystansu społecznego, i to nierzadko $\mathrm{w}$ dół hierarchii, osobiste doświadczenia często były opisywane jako mniejszy lub większy szok. W polskim pamiętnikarstwie mamy wiele relacji $z$ tego rodzaju doświadczeń związanych z wojną. Na przykład pisarka Zofia Nałkowska i adwokat Halina Wardell znalazły się w tłumie uchodźców z Warszawy we wrześniu 1939 roku, w tym kryzysowym czasie spotkały się z gościnnością chłopskich rodzin i opisały ją później. Mimo deklarowania wdzięczności zapamiętały też oznaki „cielesnego oporu”, jakiego doświadczyły, zderzając się z trudniejszymi warunkami życia. Dla nas interesujące jest to, że odarty $z$ form gościnności gest gospodarzy nie tylko zachował wartość, ale nawet zyskał jeszcze większą, w warunkach bezpośredniego wspólnego zagrożenia. Jednak być może nie należy ignorować faktu, że opisywane w tych wspomnieniach szczere, i w miarę możliwości szczodre, a nawet czasem zbyt szczodre, przyjmowanie gości dotyczyło osób na pozycjach niżej położonych w hierarchii, tak jakby w roli gospodarzy niedostępna im była możliwość odmowy. Ponadto najprawdopodobniej mimo ponoszenia relatywnie wysokich kosztów materialnych, dzieląc $z$ gośćmi podobnie silne zagrożenie, nie tylko w warunkach kryzysu, ale także po jego ustaniu nie mogli liczyć na społeczny zysk z powodu ugoszczenia osób z „wyższymi zasobami” .

Cytat 13. (Zofia Nałkowska [1884-1954] 1972, s. 33-35):

Po drodze jakaś gosposia wyszła przed zagrodę i poprosita nas na kawę. Mój Boże! z jakimż wzruszeniem piłam tę wodę bez cukru, zabarwiona z lekka na żótty kolor, 
o którym powiedziano nam, że prócz kawy dodali też trochę herbaty, i za nic przyjać nie chcieli zapłaty, tak że trzeba było dawać coś w prezencie dzieciom. Piliśmy to na dziedzińcu, siedząc po części na przyniesionych krzesłach, prowadząc towarzyska rozmowę o wojnie $z$ wielu osobami tej rodziny. [...]

Stary, gtuchy gospodarz okazuje się czarująco gościnny $i$ bezinteresowny, do izby przynosza stomy, śpimy skwapliwie wśród much $i$ upatu.

\section{Cytat 15. (Halina Wardell [?1909-1987] 1972, s. 59):}

Gospodyni odstapiła nam izbę z łóżkiem. Izba bielona, łóżko krótkie, petne pierzyn, udekorowane prawie do sufitu coraz to mniejszymi poduszkami. Zaduch stęchlizny i zapach gnojówki pod oknem. Mała, Zocha i Jędruś zasnęli, ja dusiłam się, gdyż płuca przyzwyczajone do świeżego powietrza nie chciały się pogodzić z zaduchem, a poza tym pchty $i$ muchy nie pozwalały leżeć spokojnie. Wyszłam przed chałupe. Na ławce oparty o ściane drzemat mą̇, któremu robactwo $w$ sianie nie dało zasnać $w$ stodole. Przysiadłam obok i oparci o siebie zasnęliśmy.

Pamięć okresu wojennego i powojennego zapisana we wspomnieniach przywołuje zarówno gościnnie otwarte, jak i zatrzaśnięte drzwi. Jak wynika z opisów, dla niektórych był to czas nauki eliminowania gościnności ze swojego życia na rzecz dbania przede wszystkim o własne bezpieczeństwo i życie, przy czym rozłożenie zobowiązań do udzielenia gościny za wszelką cenę oraz praw do skorzystania $z$ niej i odmowy jej udzielenia zależało od statusu uczestników relacji. Wyglądało, że łatwiej odmówić gościny osobom o statusie niższym, choć zmiana statusu następowała pod wpływem warunków kryzysu. Brak takich gestów pomocy, gdy były one szczególnie potrzebne, dla autorów wspomnień stanowił doświadczenie, z którym niełatwo było im się pogodzić. Przywołam dwie relacje $z$ takich sytuacji. Autorką dwóch fragmentów (cytaty 16 i 17) jest Paulina (Ola) Watowa, podobnie jak jej mąż Aleksander Wat pisarka i działaczka komunistyczna pochodzenia żydowskiego. Opisywane zdarzenia dotyczą okresu drugiej wojny, zesłania i uwięzienia Aleksandra oraz sytuacji małżonków w kraju wkrótce po wojnie i dojściu do władzy komunistów. Drugim autorem (cytaty 18, 19,20) jest Marian Brandys, który opisał doświadczenia związane z opozycyjnym zaangażowaniem jego żony, Haliny Mikołajskiej, działaczki KOR w latach siedemdziesiątych XX wieku. Mimo różnego kontekstu społeczno-politycznego poczucie opuszczenia przez przyjaciół, osamotnienia i rosnącego zagrożenia, wynikające $z$ braku przyjacielskich wizyt, braku zaproszeń do odwiedzin oraz nieszczerości w trakcie spotkań w gościnie, w obu przypadkach było podobne. Autorzy opisali naznaczenie osoby, która ze względu na splot zewnętrzynych okoliczności została określona jako niosąca zagrożenie i na mocy tego naznaczenia została niejako wypchnięta $z$ kręgu, gdyż spotykała się nie z jednostkowymi i jednorazowymi odmo- 
wami ugoszczenia, lecz z zachowaniami powtarzającymi się z wielu stron („solidarnymi” w tym sensie), budującymi skumulowany efekt towarzyskiej i społecznej izolacji.

Cytat 16. (Paulina [Ola] Watowa [1903-1991] 2000 [wsp. ze Lwowa 1940], s. 35): [...] obserwacje ograniczaja się raczej do gorzkich doświadczeń catkowitego opuszczenia przez najbliższych przyjaciót, sparaliżowanych przez lęk o wtasna skórę. Nie biorę im tego za zte. Strach byt wielki, a przyszłość przerażająca. Toteż nikt nie przyszedt do mnie, żeby dowiedzieć się, jak sobie radze, czy mi można $w$ czymś pomóc. Odczułam to wszystko okropnie, bo niewymierna samotność po aresztowaniu Aleksandra powiększyła się jeszcze o tę inna samotność, o odejście przyjaciót, o ich najpewniej przymusowa — obojętność.

Cytat 17. (Paulina [Ola] Watowa [1903-1991], 2000, s. 52):

Wszyscy ci ludzie, którzy spodziewali się na ogót wywózki, wieźli ze soba olbrzymie zapasy rzeczy, a przede wszystkim masę żywności. Pamiętam gary smalcu, worki sucharów, suszonych owoców, cukru i tak dalej. Ja natomiast, uciekinierka $z$ Warszawy, $z$ matym tłumoczkiem, nie posiadałam nic. I $w$ ciagu tej trzytygodniowej podróży w bydlęcym wagonie $z$ ciagtymi prowierkami, żywieni wytacznie noca - to znaczy przynoszono do wagonu wiadro zupy, przeważnie bardzo pomyjowatej, i po porcji czarnego, gliniastego chleba — myśmy z Andrzejem skazani byli tylko na to odżywianie. Andrzej budzony w nocy nie chciat jeść, byt jeszcze „rozpieszczony”, nieprzyzwyczajony do tych warunków, a w ciagu dnia nie mógt się zmusić do przetknięcia zimnych pomyj. Mieli maszynki spirytusowe, ale nie pozwolili mi skorzystać, aby odgrzać zupę. Sytuacja była wręcz tragiczna, widziałam, jak Andrzej marnieje z dnia na dzień. Ani jedno sumienie ludzkie, ani jeden odruch chrześsijańskiego wspótczucia.

Cytat 18. (Marian Brandys [1912-1998] 1996 [wsp. z lat 1976-1977] s. 28-29): Halina wrócita $z$ Krakowa roztrzęsiona [...] zachowaniem Wicki. Opowiadała o jej przerażeniu inwigilacja policyjna, o jej ciagtych lamentach i rozważaniach $w$ zwiazku z grożącymi jej przestuchaniami, o jej wyraźnej chęci pozbycia sie jak najprędzej Haliny z domu. Kiedy Halina powiedziała wreszcie, że nie będzie już więcej przyjeżdżała, aby nie zakłócać jej spokoju — wieloletnia najbliższa przyjaciótka nie zdobyła się nawet na gest konwencjonalnego protestu, tylko w milczeniu opuścita głowę. Halina nie może o tym mówić bez łez: po trzydziestu latach siostrzanej przyjaźni takie zakończenie!

Cytat 19. (Marian Brandys [1912-1998] 1996 [wsp. z lat 1976-1977] ):

„Najgorsza jest ta Sahara, jaka wytwarzaja wokót nas — mówi Halina. —Wszystkie te brutalne, matpio ztośliwe dokuczliwości można jeszcze jakoś wytrzymać, ale narastająca pustka jest trudna do zniesienia". Uważa, że będzie z tym coraz gorzej, że coraz ostrzejszymi środkami będa odstraszać od nas ludzi: „Postaraja się o to, zobaczysz jeszcze, jakie gówno będzie się lało na nasze głowy z tego telewizora!"

Kiedy czytamy takie wspomnienia, nasuwa się pytanie o to, w jakim stopniu pamięć długotrwałych lub powtarzających się w historii przypadków kryzysów społecznych uwarunkowanych politycznie doprowadziła 
nie tylko do trwałego rozchodzenia się kręgów towarzyskich na zaufane i wrogie, a potem także do wnikania przedstawicieli wrogów do tak ukształtowanych kół towarzyskich, pozostawiła trwały ślad w charakterze stosunków opartych na gościnach domowych, podkopując ich solidarnościowy potencjał konstruktywnej transformacji.

Cytat 20. (Marian Brandys [1912-1998] 1996 [wsp. z lat 1976-1977], s. 30):

Wczoraj niespodziewana wizyta R., mojego kolegi z oflagu (po kilku latach niewidzenia sie, nagle z rana zadzwonit i po prostu wprosit się). Mity, kulturalny, wywodzacy się z samej elity przedwojennej, obdarzony różnymi talencikami artystycznymi a przy tym wyraźnie „na usługach”. Mówia tak wszyscy, którzy mieli z nim bliżej do czynienia. Jak do tego doszło — nie wiadomo. Musieli go czymś zaszantażować $w$ pierwszych latach powojennych. W każdym razie wczoraj przyszedt na zwiad, pod pretekstem złożenia ofiary na KOR. Zdradzały go spojrzenia i rzucane od czasu do czasu pytania: jednoznaczne, prymitywne, nielicujace $z$ poziomem jego inteligencji i kultury. Chciato mi się rzygać, rzygać, rzygać!

W ocenie takich sytuacji trzeba koniecznie zaznaczyć, że ich warunki określały na ziemiach polskich kolejne silne i wrogie reżimy państwowe (najpierw carski i pruski, potem hitlerowski, radziecki oraz polski pozostający pod jego wpływem) i że każdy gość mógł wówczas nieść ze sobą niebezpieczeństwo, także dawny przyjaciel. Obrazuje to dobrze przywołana ostatnio gorzka notatka (cytat 20). Jej autor zastanawia się, jak to się stało, że człowiek o wysokich przymiotach towarzyskich zmienił się i stał się wrogiem, jak to się stało, że złamano jego ducha i zburzono moralność, „za ile” się sprzedał, niegodny zaufania, „podwójny” we własnych i przypisywanych mu intencjach, w tym sensie „nieludzki”, niebezpieczny, nieszczery. Grupami odniesienia stały się niejasne, częściowo w sposób tajny zawiązywane pakty lojalnościowe, co musiało mieć konsekwencje społeczne i emocjonalne, skłaniając do zamykania się we tylko „własnym”, wąskim zaufanym kręgu (zob. Marody 1991; Tarkowski, Tarkowska 1994; Wicenty, Nawrocki 2018).

Powyższe przykłady mogłyby świadczyć o tym, że przebieg kryzysowych momentów historii jako względnie trwałych „zaburzeń" życia codziennego może przynosić wymierne konsekwencje dla charakteru relacji społecznych, obejmujące i rozkładające także kulturę gościnności, która $z$ zasady opiera się na gotowości do podejmowania ryzyka otwarcia. Warto na koniec wspomnieć, że doświadczenie traumatycznych przeżyć związanych z utratą niepodległości, wynaradawianiem, wojnami i działaniami reżimów państwowych nie stało się udziałem wyłącznie społeczeństwa polskiego. Przeciwnie, istnieją kraje czy grupy etniczne o gorszej pod tym względem sytuacji, a niszczenie kultury gościnno- 
ści jako uniwersalnego sposobu utrzymywania i zacieśniania stałych kręgów oraz przyjmowania przybyszów może mieć o wiele szersze konsekwencje.

\section{PODSUMOWANIE I WNIOSKI}

W analizowanych autobiografiach przeważała perspektywa gości i to najczęściej z tej perspektywy gościna była biograficznie ważna, zwłaszcza jeśli stanowiła „pierwsze wejście” do danego domu, kręgu społecznego, środowiska lub przeciwnie - jeśli pokazywała odrzucenie społeczne, wykluczenie i zamknięcie. Opisane sytuacje gościny są raczej wyjątkowe, bardziej znaczące od innych zwyczajowych gościn i ewidentnie związane ze zmianą. Dlatego uzasadniona wydaje się analiza na różnych wymiarach dynamiki społecznej: interakcyjnej, biograficznej i społeczno-strukturalnej.

Doświadczenia biograficzne wiązane $z$ sytuacjami gościny były ukazywane na tle obrazu struktury, która w czasie historycznym ulegała powolnemu przekształceniu lub gwałtownym załamaniom. Wśród zmian, które przebiegały wolniej, należałoby wskazać przede wszystkim zastąpienie silnych i klarownych tradycyjnych zróżnicowań i barier społecznych przez bardziej demokratyczne relacje towarzyskie oraz autonomizację i emancypację kategorii wcześniej podporządkowanych i zależnych. Z przemianami tymi wiązał się jednak wzrost niejasności i niepewności co do istnienia i charakteru barier społecznych oraz ich nowych wyznaczników, takich jak odpowiedni światopogląd czy udział w wojnie lub w walce politycznej w określonej roli. Walka o swoje miejsce w strukturze społecznej i udział w jej przekształcaniu wpływały na postrzeganie i ocenę sytuacji gościny oraz ich uczestników. Wskazałabym tu na skłonność do idealizacji kręgu osób dotychczas wyższej postawionych lub, przeciwnie, porzucenie skłonności do ich idealizacji i wyostrzone, krytyczne dystansowanie się od nich na rzecz zbliżania się do innych środowisk. Rezultaty badań wskazują na niepokojący fakt, że dotkliwe i doświadczane w skali zbiorowej kryzysowe sytuacje społeczne nie tylko przyczyniały się do okresowego podważania norm i niszczenia kultury gościnności, ale też sprzyjały długotrwałemu utrzymymywaniu się ostrożności, nieufności, podejrzliwości i obaw bezpośrednio wpływających na praktyki i doświadczenia gościnności.

Wyniki przeprowadzonej analizy sugerują zatem, że w czasach względnej stabilności szczególnie ważne $z$ perspektywy autobiograficznej jest to, że niektóre sytuacje gościny mają znaczenie w procesie dokonywania 
przejść między nieodległymi od siebie pozycjami w strukturze społecznej i mogą wiązać się z awansem społecznym. Natomiast w warunkach nasilonych zmian społecznych i kryzysów z jednej strony możliwe stają się wizyty domowe nieproszonych gości reprezentujących bardzo odległe pozycje $\mathrm{w}$ hierarchii, a $\mathrm{z}$ drugiej $-\mathrm{z}$ czasem może nastąpić podważenie lub odrzucenie tradycyjnych wymogów gościnności na rzecz zamknięcia i ochrony najbliższych kręgów.

Na koniec warto zwrócić uwagę, że analizowane materiały potwierdzają spostrzeżenia Floriana Znanieckiego (1938), według którego generalnie gościnność nie jest neutralna wobec hierarchii spo$ł$ ecznych, co oznacza, że normy gościnności nie obowiązują wszystkich jednakowo, w różnym stopniu obciążają jednych, a innym dają więcej korzyści. W czasach kryzysowych zjawisko to nasila się, ponieważ presja społeczna na przestrzeganie wymogów gościnności w większym stopniu oddziałuje na osoby o niższych zasobach, przy czym pozostający w szczególnie trudnej sytuacji życiowej zaczynają być uznawani za niosących zagrożenie, co staje się usprawiedliwieniem wykluczania ich z gościnnych kręgów.

\section{BIBLIOGRAFIA}

Candea Matei, da Col Giovanni, 2012, The Return to Hospitality, „Journal of the Royal Anthropological Institute", t. 18, nr 1, s. 1-19.

CBOS, 2010, Powody do dumy i wstydu dla Polaków. Komunikat z badań. BS/30/2010, Warszawa, marzec.

Cieśla Joanna, 2017, Sondaż POLITYKI: Jak Polacy postrzegaja samych siebie? „Polityka”, 1 sierpnia, [omówienie badań przeprowadzonych przez Kantar Public].

Conway Martin A., Pleydell-Pearce Christopher W., 2000, The Construction of Autobiographical Memories in the Self-Memory System, „Psychological Review”, t. 107, s. 261-288.

Czyżewski Marek, 2016, Socjologia interpretatywna i metoda biograficzna: przemiana funkcji, antyesencjalistyczne wątpliwości oraz sprawa krytyki, „Przegląd Socjologii Jakościowej”, t. 9, nr 4, s. 14-27.

Cymbrowski Borys, 2017, Szlachcic mieszczaninem? Zmiany społeczne na przykładzie wybranych bohaterów XIX-wiecznych powieści, „Roczniki Nauk Społecznych”, t. 9 (45), nr 4, s. 187 -209 .

Derrida Jacques, 2000, Of Hospitality, tłum. R. Bowlby, Standford University Press, Stanford [De l'hospitalité, Callmann-Lévy, 1997].

Długosz Jan, 1961, Dziejów polskich ksiag XII, tłum. Karol Mecherzyński, w: Artur Bardach, Stanisław Herbst (red.), Kultura polska w źródłach $i$ opracowaniach, Ludowa Spółdzielnia Wydawnicza, Warszawa.

Doliński Wojciech, 2012, Nowe ślady, stare drogi. Europa w pamiętnikach Polaków, Nomos, Kraków.

Elias Norbert, 2011 [1939], O procesie cywilizacji. Analizy socjo- i psychogenetyczne, tłum. Tadeusz Zabudowski, Kamil Markiewicz, Wydawnictwo WAB, Warszawa. 
Gibson Sarah, 2003, Accomodating Strangers: British Hospitality and the Asylum Hotel Debate, „Journal for Cultural Research”, t. 7, nr 4, s. 367-386.

Goffman Erving, 1981. Człowiek w teatrze życia codziennego, tłum. Helena Datner-Śpiewak, Paweł Śpiewak, Państwowy Instytut Wydawniczy, Warszawa.

Goffman Erving, 2006, Rytuat interakcyjny, tłum. Alina Szulżycka, Wydawnictwo Naukowe PWN, Warszawa.

Gomulicki Juliusz W., 1959, Wstęp, w: Paulina Wilkońska, Moje wspomnienia o życiu towarzyskim w Warszawie, Państwowy Instytut Wydawniczy, Warszawa.

Janaszek Ivanickova Halina, 1971, Świat jako zadanie inteligencji. Studium o Stefanie Żeromskim, Państwowy Instytut Wydawniczy, Wraszawa.

Janion Maria, 2009, Bohater, spisek, śmierć. Wykłady żydowskie, Wydawnictwo WAB, Warszawa. Jedlicki Jerzy, 2002, Jakiej cywilizacji Polacy potrzebuja, Wydawnictwo WAB, Warszawa.

Kant Immanuel, 1995 [1795], O wiecznym pokoju, tłum. Feliks Przybylak, Wydawnictwo Uniwersytetu Wrocławskiego, Wrocław.

Kaźmierska Kaja, 2008, Biografia i pamięć: na przykładzie pokoleniowego doświadczenia ocalonych z zagłady, Nomos, Kraków.

Komorowska Jadwiga, 1984, Świąteczne zwyczaje domowe w wielkim mieście. Studium na przykładzie Warszawy, Wydawnictwo Naukowe PWN, Warszawa.

Kromer Marcin, 1961 [1577], Polska czyli o położeniu, obyczajach, urzędach Rzeczypospolitej Królestwa Polskiego, tłum. Ludwik Kondratowicz, w: Artur Bardach, Stanisław Herbst (red.), Kultura polska w źródłach i opracowaniach, Ludowa Spółdzielnia Wydawnicza, Warszawa.

Krukowska Joanna, Rancew-Sikora Dorota, 2018, Social Contexts of Food Exclusion, „Studia Humanistyczne AGH", t. 17, nr 2, s. 43-62.

Kulas Piotr, 2016, Pomiędzy autobiografia a biografia. Biografia literacka jako źródło badań socjologicznych, „Przegląd Socjologii Jakościowej”, t. 9, nr 4, s. 64-81.

Kulas Piotr, 2017, Inteligencja zaprzeczona: etos i tożsamość młodych inteligenckich elit, Scholar, Warszawa.

Lashley Conrad, Lynch Paul, Morrison Alison (red.), 2006, Hospitality: A Social Lens, Elsevier, Oxford.

Lashley Conrad, Morrison Alison, 2000, In Search of Hospitality: Theoretical Perspectives and Debates, Butterwotyh-Heiemann, Oxford.

Levinas Emmanuel, 1998, Całość i nieskończoność. Esej o zewnętrzności, tłum. Małgorzata Kowalska, Wydawnictwo Naukowe PWN, Warszawa.

Lynch Paul, Germann Molz Jennie, McIntosh Alison, Lugosi Peter, Lashley Conrad, 2011, Theorizing Hospitality, „Hospitality and Society”, t. 1, nr 1, s. 3-24.

Łoziński Władysław, 1961 [1912], Życie Polski w dawnych wiekach, w: Artur Bardach, Stanisław Herbst (red.), Kultura polska w źródłach i opracowaniach, LSW, Warszawa, s. 310-313.

Małkowicz-Daszkowska Zofia, 2019, Dzieci w okolicznościach gościny, w: Bogumiła Mateja-Jaworska, Marta Skowrońska (red.), Gość w dom. Wspótczesne praktyki przyjmowania gości, Wydawnictwo Naukowe UAM, Poznań.

Marody Mirosława (red.), 1991, Co nam zostało z tych lat... Społeczeństwo polskie u progu zmiany systemowej, Aneks, Londyn.

Marotta Vince, 2005, Urban Sociology and the Stranger, TASA Conference Proceedings, Sociological Association of Australia, Hawthorn, Vic., s. 1-10 (http://hdl.handle.net/10536/ DRO/DU:30005906). 
Marotta Vince, 2011, Home, Mobility and the Encounter with Otherness, w: Fethi Mansouri, Michele Lobo (red.), Migration, Citizenship and Intercultural Relations: Looking through the Lens of Social Inclusion, Routledge, London-New York, s. 193-208.

Mateja-Jaworska Bogumiła, Skowrońska Marta (red.), 2019, Gość w dom. Wspótczesne praktyki przyjmowania gości, Wydawnictwo Naukowe UAM, Poznań.

Mauss Marcel, 1973, Szkic o darze. Forma $i$ podstawa wymiany $w$ spoteczenstwach archaicznych, tłum. Krzysztof Pomian, w: Marcel Mauss, Socjologia i antropologia, Państwowe Wydawnictwo Naukowe, Warszawa, s. 211-415.

Pisarek Adam, 2016, Gościnność polska. O kulturowych konkretyzacjach idei, grupakulturalna.pl, Uniwersytet Śląski, Katowice.

Pitt-Rivers Julian, 1968, The Stranger, the Guest, and the Hostile Host: Introduction to the Study of the Laws of Hospitality, w: John G. Peristany (red.), Contributions to Mediterranean Sociology, Mouton, Paris.

Pitt-Rivers Julian, 2012, The Law of Hospitality (reprint), „HAU: Journal of Ethnographic Theory", t. 2, nr 1.

Rancew-Sikora Dorota, 2015, Opowiadanie w społecznym układzie stołu. Analiza konwersacyjna spotkań rodzinnych, „Studia Humanistyczne AGH”, t. 14, nr 1, s. 25-43.

Rancew-Sikora Dorota, 2019, Porządek rytuału jako porządek życia. Błogosławieństwo rodziców przed ślubem w świetle analizy multimodalnej, „Studia Socjologiczne”, nr 1, s. 133-165.

Rancew-Sikora Dorota, Remisiewicz Łukasz, 2020, A Candle to Blow Out: An Analysis of First Birthday Family Celebrations, „Journal of Pragmatics” 158, s. 53-65.

Rancew-Sikora Dorota, Żadkowska Magdalena, 2017, Receiving Guests at Home by Nationally Mixed Couples: The Case of Polish Females and Norwegian Males, „Studia Migracyjne - Przegląd Polonijny", t. 166, nr 4, s. 61-86.

Selwyn Tom, 2000, An Anthropology of Hospitality, w: Conrad Lashley, Alison Morrison (red.), In Search of Hospitality, Butterworths-Heinemann, Oxford, s. 18-37.

Schütz Alfred, 2008a [1944], Obcy: esej z zakresu psychologii społecznej, w: Alfred Schütz, O wielości światów, tłum. Barbara Jabłońska, Nomos, Kraków, s. 213-224.

Schütz Alfred, 2008b [1945], Powracający do domu, w: Alfred Schütz, O wielości światów, tłum. Barbara Jabłońska, Nomos, Kraków, s. 203-212.

Simmel Georg, 2005 [1903], Obcy, w: Georg Simmel, Socjologia, tłum. Małgorzata Łukasiewicz, Wydawnictwo Naukowe PWN, Warszawa, s. 300-305.

Skowrońska Marta, 2014. Przyjmowanie gości w przestrzeni domowej jako problem granicy między publicznym a prywatnym, w: Magdalena Łukasiuk, Marcin Jewdokimow (red.), Socjologia zamieszkiwania, Wydawnictwo Naukowe Sub Lupa,Warszawa, s. 156-178.

Skowrońska Marta, 2019, Czuję się jak u siebie, ale bez przesady. Kontrola przestrzeni i opieka nad gościem — dwa wymiary asymetrii władzy w sytuacji gościny, w: Bogumiła Mateja-Jaworska, Marta Skowrońska (red.), Gość w dom. Wspótczesne praktyki przyjmowania gości, Wydawnictwo Naukowe UAM, Poznań, s. 97-130.

Smoczyński Rafał, Zarycki Tomasz, 2017, Totem inteligencki: arystokracja, szlachta i ziemiaństwo w polskiej przestrzeni społecznej, Scholar, Warszawa.

Straczuk Justyna, 2013, Cmentarz i stół. Pogranicze prawosławno-katolickie w Polsce i na Białorusi, Wydawnictwo Uniwersytetu Mikołaja Kopernika, Toruń.

Szopa Katarzyna, 2014, Gość inność. Etyka gościnności w filozofii Luce Irigaray, „Wakat” (http:// wakat.sdk.pl/gosc-innosc-etyka-goscinnosci-w-filozofii-luce-irigaray). 
Tarkowski Jacek, Tarkowska Elżbieta, 1994, „Amoralny familizm”, czyli o dezintegracji społecznej w Polsce lat osiemdziesiątych, w: Jacek Tarkowski, Socjologia świata polityki. Wtadza i społeczeństwo w systemie autorytarnym, t. 1, Instytut Studiów Politycznych PAN, Warszawa.

Wasilewski Jacek, 2011 [1986], Społeczeństwo polskie, społeczeństwo chłopskie, „Studia Socjologiczne", nr 1, s. 353-368.

Wicenty Daniel, Nawrocki Karol (red.), 2018, Brudne wspólnoty. Przestępczość zorganizowana w PRL w latach siedemdziesiątych $i$ osiemdziesiatych XX wieku, IPN, Gdańsk-Warszawa.

Wood Margaret Mary, 1934, The Stranger: A Study in Social Relationships, Columbia University (https://babel.hathitrust.org/cgi/pt?id=mdp.39015062952844;view=1up;seq=8).

Znaniecki Florian, 1938, Socjologiczne podstawy ekologii ludzkiej, „Ruch Prawniczy, Ekonomiczny i Socjologiczny", t. 18, nr 1, s. 89-119.

\section{Cytowane materiały autobiograficzne}

Bobińska Helena, 1963, Pamiętnik z tamtych lat, część 1, Państwowy Instytut Wydawniczy, Warszawa.

Brandys Marian, 1996, Dziennik 1976-1977, Iskry, Warszawa.

Nałkowska Zofia, 1972, Dzienniki czasu wojny, Czytelnik, Warszawa.

Niemcewicz Julian Ursyn, 2000 [1823], Pamiętniki czasów moich, t. 1, Tower Press, Gdańsk.

Pamiętnik nr 1363/222 Z.M.W. z pow. Kobryń, syn dworskiego parobka, ur. 1909 r., w: Józef Chałasiński, Młode pokolenie chłopów, t. 1, 1984 [1938], Ludowa Spółdzielnia Wydawnicza, Warszawa, s. 165-181.

Pamiętniknr 3, w: Pamiętniki bezrobotnych. Nr 1-57, t. 1 [reedycja publikacji Instytutu Gospodarstwa Społecznego, wstęp Ludwik Krzywicki], 1967 [1933], Państwowe Wydawnictwo Ekonomiczne, Warszawa.

Słomka Jan, 1912, Pamiętniki włościanina: od pańszczyzny do dni dzisiejszych, Krakowska Drukarnia Nakładowa, Kraków (https://www.pbc.rzeszow.pl/dlibra/publication/14905/edition/13621/content?ref=desc).

Szymanowska Zofia, 1980, Opowieść o naszym domu, Polskie Wydawnictwo Muzyczne, Kraków.

Świdrowski Józef, 1980, Moja droga w świat. Wspomnienia 1906-1939, Państwowy Instytut Wydawniczy, Warszawa.

Wardell Halina, 1972, Bez paszportu i dewiz. Wspomnienia 1939-1947, Czytelnik, Warszawa.

Watowa Ola, 2000. Wszystko co najważniejsze..., Czytelnik, Warszawa.

Wilkońska Paulina, 1959 [1871], Moje wspomnienia o życiu towarzyskim w Warszawie, Państwowy Instytut Wydawniczy, Warszawa.

Wysocki Alfred, 1974, Sprzed pót wieku, Wydawnictwo Literackie, Kraków.

Żeromski Stefan, 1964, Dzienniki, t. 3, Czytelnik, Warszawa.

\section{POLISH HOSPITALITY IN THE LIGHT OF AUTOBIOGRAPHICAL MEMORIES}

Dorota Rancew-Sikora

(University of Gdańsk)

\section{Abstract}

In order to describe the features of Polish hospitality, autobiographical records containing memories of hospitality from various historical periods were compiled. 
The research material included about 300 episodes from 30 published sources. A targeted selection was made according to a combination of three criteria: a diversity of social positions among the authors, the biographies of the authors, and the detail of description. An analysis of the material was conducted in order to contribute to a better understanding of the social significance of hospitality. Theoretical assumptions about hospitality in conditions of stability and social crisis were advanced. The analysis showed that in times of relative stability, hospitality was biographically important when it allowed a person to transition between positions in the social structure (usually between close levels) and involved some form of promotion. On the other hand, in conditions of intensified change and crises, the order was disturbed: on the one hand, visits to the homes of persons occupying more distant positions in the hierarchy (both up and down the social ladder) became more common, but on the other hand, there could be a challenge to or rejection of traditional requirements of hospitality. The first situation occurs especially at the beginning of a crisis, and with the depletion of resources, the increase in the number of negative experiences, and socialization to a long-term threat, a survival strategy begins to take shape in which only the closest circles prevail. Such findings suggest that a more cautious look should be taken at both the theoretical concepts in which hospitality is considered a useful social invention especially in times of increased need and at the Polish self-stereotype as a nation with a culture based on hospitality, invariable generosity, and an inclination to selflessness.

Key words: biographical perspective, episodic memories, social mechanisms of hospitality, social mobility, crisis

Stowa kluczowe: perspektywa biograficzna, pamięć epizodów, społeczne mechanizmy gościnności, ruchliwość społeczna, kryzys 